\title{
THE ROLE OF THE RELIGIOUS COMPONENT IN THE HISTORY OF THE FORMATION OF CRIMEAN KARAIM ETHNOCULTURE
}

\author{
(C) Irina K. Zholobova
}

\author{
Rostov State Medical University, Rostov-on-Don, Russian Federation \\ science-almanac@mail.ru
}

The article provides historiographic information that allows us to consider various approaches to the problem of the emergence of Crimean Karaites, to reveal the main ethnoculturological and religious features of this now small people due to a combination of factors such as the specificity of the territory of their stay, neighborhood with various peoples, many of which are very close to each other in terms of the features of religion, language and individual traditions. The main content of the article is devoted to the study of religion (Karaism), religious worship, confession of faith, traditions of Crimean Karaites as an integral part of their ethnoculture. In addition, the conducted historical and cultural analysis allows us to refer to the question of the multinational nature of Crimea, currently the Republic of Crimea, a territorial subject of the Russian Federation, where many indigenous and non-indigenous peoples lived and live, distinguished by their ethnicity, culture and religion. Their coexistence could not but leave its mark in the process of forming the ethnoculture of Crimean Karaites, their identity. It is noted that modern conditions are associated with the strengthening of the processes of "ethnic revival" and, at the same time, with the activation of assimilation processes that erode ethnoculturological boundaries.

Key words: ethnoculture, religion, identity, Crimean Karaites, Karaism, the Republic of Crimea, assimilation, traditions.

\section{[И.К. Жолобова Роль религиозного компонента в истории фоорирования этнокультуры крым- ских караимов] \\ В статье приводятся историографические сведения, позволяющие рассмотреть различные подхо-} ды к проблеме возникновения крымских караимов, раскрыть основные этнокультурологические и религиозные черты этого, ныне малочисленного народа, обусловленные совокупностью таких фракторов, как специфика территории их пребывания, соседство с различными народами, многие из которых между собой очень близки в том, что касается особенностей вероисповедания, языка и отдельных традиций. Основное содержание статьи посвящено изучению религии (караимизма), религиозного культа, вероисповедания, традиций крымских караимов как неотъемлемой части их этнокультуры. Кроме того, проведённый историко-культурологический анализ позволяет коснуться вопроса о многонациональности Крыма, в настоящее время - Республики Крым - субъекта Российской Федерации, на территории которого проживало и проживает немало коренных и пришлым народов, отличающихся своей этнической принадлежностью, культурой и вероисповеданием. Их сосуществование не могло не оставить свой след в процессе формирования этнокультуры крымских караимов, их идентичности. Отмечается, что современные условия связаны с усилением процессов «этнического возрождения» и, одновременно, с активизацией процессов ассимиляции, размывающих этнокультурологические границы.

Ключевые слова: этнокультура, религия, идентичность, крымские караимы, караимизм, Республика Крым, ассимиляция, традиции.

Irina K. Zholobova - Assistant, Rostov State Medical University, Rostov-on-Don, Russian Federation.

Жолобова Ирина Константиновна - ассистент, Ростовский государственный медицинский универcumem, г. Ростов-на-Дону, Российская Федерация.

Religion as a phenomenon of spiritual order has always been and continues to be one of the most important aspects of human existence. The ongoing processes of globalization associated with various crisis phenomena lead to the fact that there is "an increase in religious consciousness due to the deep contradictions between aspiration of the person to the ideal forms of social existence and his capabilities, which determines the highest value in the 
conversion to religion, consisting in the development of the creative potential of the individual and individuality, contributing to the avoidance of reality with problems of a daily nature into the field of transcendental (religious) things" [4]. Modern sociocultural realities indicate that religion, religious views, have undergone certain transformations, but have not lost their influence on human life. Under the influence of religion as a component of ethnoculture and religious worldview, a religious identity is formed, which, in turn, leads "to the actualization of the processes of self-identification, changes in value orientations and personal characteristics" [4] of the individual.

No less urgent is the problem of the so-called "activation of ethnic revival processes," the search for ethnic and cultural roots, the self-identification of small peoples [10], which, according to Sh.I. Berdiev, "among individuals and entire peoples manifests itself in various forms: from attempts to resuscitate ancient customs and rites, folklorization of professional culture, the search for a "mysterious folk soul" to the desire to create or restore national statehood " [2, p. 3]. To a large extent, processes of assimilation connected with the problem of ethnic and religious self-identification, which are destructive for ethnocultural identity, also contribute to such aspirations.

According to Yu.M. Plyusnin, "even in the case of leveling the most important political factor, modern socio-cultural and accompanying socio-population (demographic) factors have a significant assimilation effect. In some cases, they have acquired critical acuity and distinct manifestation" [9, p. 210]. Taking place sociocultural transformations are reflected in people's worldviews and values [6]. At the same time, the religious identity of the individual is of particular interest, which relying on the work of M.V. Vereshchagina and A.S. Soboleva, we understand as: "identifying oneself to a certain faith on the basis of an individual's awareness of his or her membership in a particular religious group, which, on the one hand, is realized through the willingness of the individual to accept and share values, ideas, norms, rules, beliefs and attitudes of this religion, and on the other hand, is determined by the desire to be a part of a certain religious community, which arises under the influence of the existential need of a person to organize and determine the world and himself in this world in order to gain the meaning of life and subjective integrity" [4].

It is the simultaneous accounting of cultural, historical, religious and ethnic components that allows us to approach the study of issues related to the contact and intersectionality of religion (faith, religious consciousness, religious identity, world view of the believer, features of worship) with the phenomenon of ethnoculture. These topical scientific problems, considered on the example of individual people, are of great interest, and they are the subject of numerous specialized and interdisciplinary studies.

Within the framework of this article, it is proposed, in particular, to consider the influence of religion, in all its manifestations, on the process of forming the ethnoculture of Crimean Karaites, developed in historical retrospect.

Crimean Karaites for many centuries, passing through various historical events, took into account their own culture, different features and features of the arriving and then disappearing peoples, forming their ethnos with its culture, religion and mentality, in other words, its unique ethnoculture.

It should be noted that ethnic culture traditionally refers to a combination of traditional values, relationships and behavioral features enshrined in the material, spiritual and social life of an ethnic group that has developed in the past and which has been developing in historical sociodynamics. Since the process of formation of ethnoculture is inextricably connected with the ethnogenesis of the people, that's why that it is appropriate to begin our analysis with it.

A special difficulty in studying this topic, first of all, is due to the fact that, as V.S. Kropotov noted, until a certain time, the actual possibility of conducting ethnographic studies among Crimean Karaites excluded official representation in the person of the clergy, as well 
as isolation and patriarchy, as an image of the life style of the people. Therefore, the issues of the ethnic culture of the Karaites of Crimea began to be explored in Russia quite late: works on the essence of the ethnic and cultural foundations of the Crimean Karaite people began to appear only from the middle of the 19th century. Nevertheless, it must be said that the bibliography at the moment is quite extensive and even though with a certain "delay," but such prominent researchers were engaged in issues of the history of the cultural heritage of Karaites, ethnogenesis, language and religion at that time (in Crimea and beyond) as the head of the Soviet anthropological school, academicians V.P. Alekseev, V. Gordlevsky, academicians V. Grigoriev, T. Kovalsky, V. Radlov and others.

In the 21st century, close attention to the problems of the modern existence of national spirituality and culture caused another wave of works devoted to the Crimean Karaite history and religious tradition. This kind of interest in Karaism is due to the fact that faith and religion played such a significant role in the fate of the Karaites that the entire history of the existence of this unique people is connected with it inextricably. At the same time, the "postmodern influence on the "sciences of spirit" was marked by the fact that researchers moved away from global theoretical constructions in the style of classical rationality, and moved to a different perusal and interpretation of existing phenomena" [3, p. 78; 5].

This study is interdisciplinary and relies on anthropological, cultural and historiographic data contained mainly in the works of V.P. Alekseev, A.A. Babadzhan, S.I. Berdiev, P. Kaleta, V.S. Kropotov, N.V. Kropotova and others.

The analysis of scientific works indicates the existence of two main versions of the origin of the Karaites: Semitic (Jewish) and Khazar (Turkic). According to Semitic theory, the Karaites come from an ethnolinguistic or ethno-confessional group of Jews who professed pre-Rabbinic Judaism. The Khazar theory indicates that the Karaites are descendants of the Khazars, the Turkic nomadic people of the 7th-10th centuries, who adopted Judaism and among the areas of settlement of which there was Crimea. The relationship of the Karaite religion with Judaism speaks in favor of the first theory. Whereas, the proximity of the language, folklore, traditions and a number of other signs of this ethnos to the Turkic peoples speaks in favor of the second theory.

Academician Alekseev V. P., speaking about the origin of Crimean Karaites back in 1972, noted that it was anthropology that made it possible to answer the question of who their ancestors were: "The Karaites are associated with the Khazars with direct and proximate genetic continuity, they come from the Khazars, and not from the ancient Jews, with whom ethnically have nothing in common" [7].

A certain clarity in resolving this discussion was also made by the work of Kropotov $\mathrm{V}$. S., who emphasized the inextricable connection between the ethnogenesis of Crimean Karaites, the formation of their ethnoculture and religious factor. So, in his opinion, "an autochthonous regional nation develops in Crimea at the turn of the 8th-9th centuries (the beginning of ethnogenesis). The formation of the ethnos occurs as a result of ethnogenetic mixing on the basis of the merger of Turkic nomadic tribal formations and local ethnic groups in the interfluve of the Alma and the Kachi. In the early stages of ethnogenesis (the 9th-10th centuries), the practise of religious teachings adopted in the Khazar Khaganate (most likely mosaism (the teachings of Moses, Jewish Religion)) was formal and did not affect the deep foundations of the worldview, which was based on ancient Turkic Tengrianism" [7]. Academician A.N. Samoilovich, the author of an article on the folk literature of Crimean Tatars and Karaites, also pointed to the Khazar component in the cultural and religious heritage of the Karaites as an echo of cultural and not linguistic relations in the era of the Khazar Kingdom. According to researchers, the new religion distinguished the Crimean-Karaite ethnic community among other ethnic formations of the Crimean region already at that time.

Karaism is a monotheistic, syncretic religion with its own dogmas, spiritual hierarchy, traditions. According to a number of religious scholars, in early Christian times Karaism as a 
doctrine fell into Crimea, and in the 8th century spread among the Khazars. "The final approval of the religious doctrine of Karaism occurred in the 11th-12th centuries during the period of mass emigration to the Crimea" [2, p. 9]. Simultaneously with the statement of the new faith, according to V.S. Kropotov, "the formation of the religious class... Karaite clergy" [7] as the most difficult process of the transition of the ancient Turkic priestly class to the positions of the new faith should have taken place."

The religious and worldview doctrine which is now recognized the national religion for the Karaites is based on the Old Testament. "People of Scripture" recognize only the Torah and do not pay sacral attention to the Talmud or other religious texts. Peter Kaleta in his monograph published in Prague in 2015, "The Mysterious Ethnos from the Crimea. The fate of representatives of the Karaite emigration in interwar Czechoslovakia" characterizes Karaism as one of the most important components of the Karaite identity. He pays great attention to the specifics of the Karaite religion and its differences from Talmudic Judaism. As the author emphasizes that the main thing for the Karaites is the Old Testament, while adherents of Talmudic Judaism, along with the Old Testament, also recognize the "oral tradition codified in the Talmud." At the same time, the Karaite religion allows believers to use any books for their self-development, including the prophetic and theological books of any religion. However, it does not undo the fact that the Torah text contains absolute truth and cannot be changed or supplemented. The main principle of the creed of Anan ben David states: "'Do not rely on me, but carefully study the Holy Scripture yourself," that is, each Karaim must study the Law himself, fulfill it and be fully responsible for his interpretation of the Law and its implementation" [1, p. 144].

Two key dogmas of Karaism are the principle of unity and justice of God. It is also necessary to indicate such principles of creed as: The world is created by God in time from Nothing; God is the creator, being the root cause of all things is not created by anyone; God is absolutely united, asomatous and comparable to nothing. "The Karaites firmly believe in retribution and retribution for good and evil deeds, in the resurrection of the dead and in eternal life (that is, if a person, in the continuation of his earthly life, prepared himself with good deeds, then when parting with this world, passes into another world, spiritual in its content, in which he will live forever)" [2, p. 15].

The Khazar component in the cultural and religious heritage of the Karaites is manifested, in particular, in the fact that for Crimean Karaites, despite the statement of Karaism, the God of heaven, a single deity, Tengri (Tanry, Teiri, Tengiri) acts as an element of spiritual culture. The appeal to this archaic name of God is characteristic of many Turkic peoples and dates back to the oldest Turkic tradition.

Other elements of the mythology of the Turkic peoples, preserved in the culture of Crimean Karaites, are archaic beliefs and superstitions associated with the cult of sacred trees. "According to the beliefs conveyed by word of mouth from elders to the younger generation, during the times of distress, drought, or difficult life situations, the head of the family could turn near the ancestral tree, in fulfillment of his desire. By showing respect for such a tree, according to the beliefs of his ancestors, thus, the man showed his respect for the most supreme Deity"[8, p. 75]. In addition, Turkic roots can be traced in the motives of religious songs, names of holidays, months.

Until recently "the Karaites observed customs associated with the cult of ancestors dating back to shamanism. Echoes of shamanism can be traced in other customs and rites, for example, in the burial one" [7].

In a later period, the spiritual culture of Crimean Karaites was subjected to other influences. Thus, "Crimean Karaites are characterized by the use of many religious and cult terms in relation to the attributes of deity, faith, shrine, etc. from the ancient Arabic language, which are sacred among Muslims" [8, p. 72]. 
This makes it possible to recognize the need for a synthetic approach in determining the factors that had a decisive influence on the process of forming the ethnic group of Crimean Karaites and their culture. Since the presence, within the religious component of ethnoculture of signs of the intersection of so many cultures, indicates the paramount importance among them of the Turkic component, the incorporation of elements of archaic religious beliefs, and the preservation of "identification codes characteristic of the Jewish ethnosocium" [2, p. 10].

Throughout the long history of the Karaites, it was religion that was the ideological support during the crisis periods of national history. Adherence to tradition, confessional isolation, the Karaite religion itself have played a special role in preserving ethnic identity and selfconsciousness, "national identity, since the Karaite religion contributed to the preservation of a conservative lifestyle (accordingly, the characteristic features of ethnoculture were preserved) and hindered the development of assimilation processes. The highest authority of outstanding representatives of the people in the person of clergy and spiritual mentors was based primarily on their ability to defend national interests" [7].

The turning point for Karaite traditionalism with the inherent conservatism of the social structure, patriarchal way of life, the duration of preservation of moral norms, customs and traditions formed in antiquity, as well as the presence of elements of relict beliefs in ethnoculture is the end of the 19th and the beginning of the 20th century. The ongoing socioeconomic transformations could not but touch the culture of the Karaites. The elements of ethnoculture inherent in the ethno-confessional community, with the revival of the characteristic features and characteristics of the people formed during the periods of its ancient history, go back to that time. "It is impossible to give an objective assessment to the origins and orientation of the changes that significantly changed the Crimean-Karaite environment, regardless of the socio-political situation in Russia: strengthening the actions of factors guiding the empire along the Western development path (primarily in economics, politics, ideology) and breaking up traditionally national things (decomposition of the peasant community and estates, crisis phenomena in the spiritual and moral, cultural sphere)" [7].

Modern trends related to the ongoing processes of globalization, assimilation, development of a tolerant attitude to other cultures, religion, and "blurring the boundaries of identity," like wars and repressions that took place in the past, which reduced the number and dismembered the once united people of the Karaites, certainly affected the ethnic culture of Crimean Karaites and its religious component, led to a certain spiritual "extinction."

Sociological studies conducted among the Crimean-Karaite population [9] indicate that some people have lost faith, do not follow the religious path of their ancestors. However, all that is said does not cancel the fact that despite all the tests, which endured by this ancient, small, dispersed, but persistent and original people, Crimean Karaites have not lost their identity, carried it through the centuries, remembered their national history and have preserved Karaism as their national religion and aspire to the revival of their ethnoculture, for which religion was and remains the binding thread, and the stronghold is the spiritual connection with the native land of Crimea.

Thus, various approaches to establishing the origins of the emergence and the modern way of identifying Crimean Karaites, the peculiarities of their way of life, historical and cultural environment in their relationship with Karaism and the role that the religion of this people played in their fate, becoming an integrating factor, a support for this people, were considered. Characterizing in general the influence of the religious factor on the formation of the ethnoculture of Crimean Karaites, it should be noted that the spiritual foundations of the Karaite people, rooted in deep antiquity, contain "echoes" of various historical eras and elements of many cultures, including Turkic and Jewish. We can say with confidence that the Crimean-Karaite ethnoculture, formed in the conditions of interpenetration and mutual influence of many cultures, continues to maintain its inherent distinctive features. 


\section{Лumepamypa}

1. Бабаджан А.А. Самостоятельность караимской религии // Вопросы крымскотатарской филологии, истории и культуры. 2016. Вып. 3. С. 142-146.

2. Бердиев Ш.И. Караимы: проблемы этнокультурной и этноязыковой идентификации // Авторефрерат диссертации на соискание ученой степени кандидата исторических наук. Нальчик, 2012.

3. Вавилова Е.Ю., Хандурова Е.Н. Религиозная идентичность: современные подходы // Инновационная наука. 2018. №7-8. С. 78-81.

4. Верещагина М.В., Соболева А.С. Теоретические аспекты изучения религиозной идентичности личности // Общество: социология, психология, педагогика. 2018.

5. Вигель Н.Л., Жолобова И.К. Культура постмодерна: трансформация идеалов // В сборнике: Перспективы развития науки и образования. Сборник научных трудов по материалам XVIII международной научно-практической конфреренции. Москва, 2017. C. 106-107.

6. Жолобова И.К. Человек, его чувства и отношения в современных социокультурных реалиях // В сборнике: Перспективы развития науки и образования. Сборник научных трудов по материалам XXVIII международной научно-практической конференции. Под общей редакцией А.В. Туголукова. 2018. С. 104-107.

7. Кропотов В.С. Специфика формирования этнической культуры крымских караимов и особенности ее проявления на различных исторических этапах развития общества / Святыни и проблемы сохранения этнокультуры крымских караимов. Материалы научно-практической конференции. Симферополь: Доля, 2008. C.109-149.

8. Кропотова Н.В. Общетюркские традиции фрольклора крымских караимов // Проблемы современной науки и образования. 2017. С. 70-76.

9. Плюснин Ю.М. Караимы Крыма. Путевые заметки к вопросу об идентичности // Идеи и идеалы. 2019. Т. 11. № 2. ч. 1. С. 209-232.

10. Vigel N., Zholobova I. Heroic epos of North Caucasus Nations as basis for ethnical culture of Adygea People // Научный альманах стран Причерноморья. 2017. №2 (10). C. 25-30.

\section{References}

1. Babajan A.A. Samostoiatelnost karaimskoi religii. Voprosy krymsko-tatarskoi filologii, istorii i kultury. [Independence of the Karaite religion. Issues of Crimean Tatar philology, history and culture]. 2016. Issue 3. pp. 142-146 (in Russian).

2. Berdiev Sh.l. Karaimy: problemy etnokulturnoi i etnoiazykovoi identifikatsii. Avtoreferat dissertatsii na soiskanie uchenoi stepeni kandidata istoricheskikh nauk. [The Karaites: problems of ethnocultural and ethno-linguistic identification. Extended abstract of dissertation for the degree of candidate of History]. Nalchik, 2012 (in Russian).

3. Vavilova E.Yu., Khandurova E.N. Religioznaia identichnost: sovremennye podkhody. Innovatsionnaia nauka. [Religious identity: modern approaches. Innovative science]. 2018. No. 7-8. pp. 78-81 (in Russian).

4. Vereshchagina M.V., Soboleva A.S. Teoreticheskie aspekty izucheniia religioznoi identichnosti lichnosti. Obshchestvo: sotsiologiia, psikhologiia, pedagogika. [Theoretical aspects of the study of the religious identity of the person. Society: sociology, psychology, pedagogy]. 2018 (in Russian). 
5. Vigel N.L., Zholobova I.K. Kultura postmoderna: transformatsiia idealov. V sbornike: Perspektivy razvitiia nauki i obrazovaniia. Sbornik nauchnykh trudov po materialam XVIII mezhdunarodnoi nauchno-prakticheskoi konferentsii. [Post-modern culture: the transformation of ideals. In the collection: Prospects for the development of science and education. Collection of scientific papers on the materials of the XVIII international scientific and practical conference]. Moscow, 2017, pp. 106-107 (in Russian).

6. Zholobova I.K. Chelovek, ego chuvstva i otnosheniia v sovremennykh sotsiokulturnykh realiiakh. V sbornike: Perspektivy razvitiia nauki i obrazovaniia. Sbornik nauchnykh trudov po materialam XXVIII mezhdunarodnoi nauchno-prakticheskoi konferentsii. [Man, his feelings and relationships in modern sociocultural realities. In the collection: Prospects for the development of science and education. Collection of scientific papers on the materials of the XXVIII International Scientific and Practical Conference]. 2018, pp. 104-107 (in Russian).

7. Kropotov V.S. Spetsifika formirovaniia etnicheskoi kultury krymskikh karaimov i osobennosti ee proiavleniia na razlichnykh istoricheskikh etapakh razvitiia obshchestva. Sviatyni i problemy sokhraneniia etnokultury krymskikh karaimov. Materialy nauchnoprakticheskoi konferentsii. [Specifics of the formation of the ethnic culture of the Crimean Karaites and the peculiarities of its manifestation at various historical stages of the development of society. Shrines and problems of preserving the ethnoculture of the Crimean Karaites. Materials of the scientific and practical conference]. Simferopol: Dolia, 2008, pp. 109-149 (in Russian).

8. Kropotova N.V. Obshchetiurkskie traditsii folklora krymskikh karaimov. Problemy sovremennoi nauki i obrazovaniia. [General Turkic traditions of Crimean Karaite folklore. Problems of modern science and education]. 2017, pp. 70-76 (in Russian).

9. Plyusnin Yu.M. Karaimy Kryma. Putevye zametki k voprosu ob identichnosti. Idei i idealy. [The Karaites of Crimea. Travel notes on the issue of Identity. Ideas and Ideals]. 2019. V. 11. No. 2. Part 1. pp. 209-232 (in Russian).

10. Vigel N., Zholobova I. Heroic epos of North Caucasus Nations as basis for ethnic culture of Adygea People. Science Almanac of Black Sea Region Countries. 2017. No.2 (10). pp. 25-30. 